\title{
Constitutive caspase-like machinery executes programmed cell death in plant cells
}

\author{
M Elbaz ${ }^{1}$, A Avni ${ }^{\star, 1}$ and M Weil ${ }^{2}$ \\ ${ }^{1}$ Department of Plant Sciences, Faculty of Life Sciences, Tel Aviv University, \\ Ramat Aviv, Tel Aviv 69978, Israel \\ 2 Department of Cell Research and Immunology, Faculty of Life Sciences, Tel \\ Aviv University, Ramat Aviv, Tel Aviv 69978, Israel \\ * Corresponding author: A Avni, Department of Plant Sciences, Faculty of Life \\ Sciences, Tel Aviv University, Ramit Aviv, Tel Aviv 69978, Israel. \\ Tel: 972-3-640-9840; Fax: 972-3-640-9380; E- mail: Ipavni@post.tau.ac.il
}

Received 10.7.01; revised 15.11.01; accepted 11.1.02 Edited by M Piacentini

\begin{abstract}
The morphological features of programmed cell death $(\mathrm{PCD})$ and the molecular machinery involved in the death program in animal cells have been intensively studied. In plants, cell death has been widely observed in predictable patterns throughout differentiation processes and in defense responses. Several lines of evidence argue that plant PCD shares some characteristic features with animal PCD. However, the molecular components of the plant PCD machinery remain obscure. We have shown that plant cells undergo PCD by constitutively expressed molecular machinery upon induction with the fungal elicitor EIX or by staurosporine in the presence of cycloheximide. The permeable peptide caspase inhibitors, zVAD-fmk and zBocD-fmk, blocked PCD induced by EIX or staurosporine. Using labeled VAD-fmk, active caspase-like proteases were detected within intact cells and in cell extracts of the PCD-induced cells. These findings suggest that caspase-like proteases are responsible for the execution of PCD in plant cells.

Cell Death and Differentiation (2002) 9, 726-733. doi:10.1038/ sj.cdd. 4401030
\end{abstract}

Keywords: caspase; defense responses; fungal elicitor; Nicotiana tabacum

Abbreviations: $\mathrm{CHX}$, cycloheximide; DIC, differential interference contrast; EIX, ethylene inducing xylanase; FDA, fluoresceindiacetate; FITC, fluorescein isothiocyanate; HR, hypersensitive response; $\mathrm{PCD}$, programmed cell death; STS, staurosporine

\section{Introduction}

Cell death is a crucial process in animal life, and is currently being recognized as such in plants as well. ${ }^{1-3}$ Programmed cell death (PCD) or apoptosis, is the mechanism by which animal cells activate an intrinsic suicide program to kill themselves. ${ }^{4-6}$ The morphological features of apoptosis and the molecular machinery involved in the death program are conserved from the nematode to humans. Most animal nucleated cells starting from the zygote are capable of undergoing PCD, and the machinery required to execute the death program is constitutively expressed. ${ }^{7}$ The observed characteristics of PCD in animal cells include condensation of the cytoplasm and nucleus, loss of cell to cell contacts in organized tissue, DNA fragmentation, formation of apoptotic bodies, blebbing and breakage of the cell membrane. ${ }^{8}$ The execution of animal PCD is mediated by the activation of a family of cysteine proteases (caspases) that cleave their target proteins at specific aspartic acid residues. ${ }^{5,6,9}$

PCD has been recognized as having a major role in plant life. ${ }^{1-3}$ Part of the plant defense response is the induction of PCD known as hypersensitive response (HR) ${ }^{10,11}$ The HR classification is based on morphological criteria of the resultant cell-death lesion. ${ }^{12,13}$ Although the $\mathrm{HR}$ is a common feature of many resistant reactions, it is not an obligatory component. ${ }^{11,14,15}$ Challenging tomato or tobacco varieties with the ethylene-inducing xylanase (EIX) elicitor causes rapid induction of different types of plant defense responses, including HR. ${ }^{16-18}$

Recent accumulating evidence suggests that animal and plant PCD systems are similar in several aspects. $2,3,10,12,13,19-21$ During the development and autolysis of xylem vessels in pea, the nuclei of cells undergoing lysis contain fragmented DNA. ${ }^{22}$ Formation of apoptotic bodies has also been reported in HR on several occasions. ${ }^{23,24}$ Other morphological similarities have also been reported, such as cytoplasm shrinkage, nuclear condensation and membrane blebbing. ${ }^{18,23,24}$ Recently, there has been growing evidence of caspase-like activity in plants. ${ }^{20,25}$ Cysteine proteases were shown to be activated during HR in fungusinfected cowpea plants, caspase-specific peptide inhibitors abolished induction of plant $\mathrm{HR},{ }^{21,26}$ and caspase specific inhibitors were shown to inhibit degradation of poly-ADPribose polymerase (PARP), a caspase specific substrate, in tobacco protoplasts. ${ }^{27}$ Moreover, caspase-3 like activity has been demonstrated in barley and chara systems. ${ }^{25}$

We provide evidence that plant cells constitutively express the proteins required to run the death program. Our data strengthens the argument that plant PCD is organized and functions in a similar way to that in the animal kingdom. In this regard we show that peptide caspase inhibitors block PCD and specifically bind to plant proteins, and we have localized this binding in cells undergoing programmed cell death.

\section{Results}

Bisbenzimide staining detects early morphological changes of cell death in $N$. tabacum cell suspension

We developed a cell viability test that identifies dead cells at an early stage of plant cell death using the UV fluorescent dye 
bisbenzimide (Hoescht 33342). This dye labels cell nuclei in animal cell cultures and is used for quantitative and nuclear morphology studies. ${ }^{28}$ We found the staining of the fluorescent dye bisbenzimide to possess higher sensitivity than Fluorescein-diacetate (FDA) staining for the purpose of observing live or dead cells (Figure 1). FDA stains living cells as confirmed by their cell morphology seen by differential interference contrast (DIC; Figure 1). In our assay healthy tobacco cells exclude bisbenzimide dye from their nuclei (as the dye cannot pass the membrane and enter the cell). Bisbenzimide staining starts when tobacco cells exhibit early morphological features of PCD such as early cytoplasm shrinkage and nuclear condensation (as judged by DIC). This takes place before FDA staining disappears. Dead cells at a more advanced stage of PCD are bisbenzimide positives only (Figure 1).

\section{Staurosporine and EIX induce PCD in tobacco cells}

To examine whether the death program in plant cells acts similarly to mammalians, we observed the induction of death in tobacco cells. N. tabacum cv Xanthi cell suspension was treated with $3 \mu \mathrm{g} / \mathrm{ml}$ of the fungal elicitor EIX (Figure 2A). This elicitor is known to elicit defense responses, including $H R$, in $N$. tabacum cv Xanthi. ${ }^{16,18,29,30}$ In a parallel set of experiments, we treated tobacco cells with $50 \mu \mathrm{M}$ staurosporine
(STS, a bacterial alkaloid that is a broad-spectrum inhibitor of protein kinases; Figure $2 \mathrm{~B}$ ) that at micromolar doses induces PCD in animal cells., ${ }^{7,28}$ To examine whether the death program in plant cells is constitutively expressed, as it was shown for animal cells, we supplemented the medium with $10 \mu \mathrm{g} / \mathrm{ml}$ of the protein synthesis inhibitor, cycloheximide $(\mathrm{CHX})$. Treatment of the cells with $\mathrm{CHX}$ did not affect the viability of the cells throughout the duration of the experiment (Figure 2; the percentage of dead cells remains about 3\%), while treatment of the cells with EIX or STS induced cell death (Figure 2; the percentage of dead cells reached $44 \%$ ). Interestingly, the presence of $\mathrm{CHX}$ together with EIX or STS did not diminish cell death percentage. Moreover, $\mathrm{CHX}$ treatment seems to enhance the PCD induced by EIX (Figure 2 ). This suggests that protein synthesis may be required for controlling the level of PCD. It can be concluded that PCD in plant cells does not require new protein synthesis.

To show that $\mathrm{CHX}$ inhibits protein synthesis in the tobacco cell suspension, we analyzed the induction of the biosynthesis of a PR (Pathogenesis related)-protein. ${ }^{30}$ Pathogenesis related proteins are a heterogeneous group of host-encoded, low-molecular-mass proteins that are synthesized by the plant in response to various stimuli, including pathogen attack. ${ }^{31}$

N. tabacum cv Xanthi cell suspension was incubated for $6 \mathrm{~h}$ in $3 \mu \mathrm{g} / \mathrm{ml}$ EIX or $50 \mu \mathrm{M}$ STS, with or without the addition of the protein synthesis inhibitor $\mathrm{CHX}$ as described
DIC
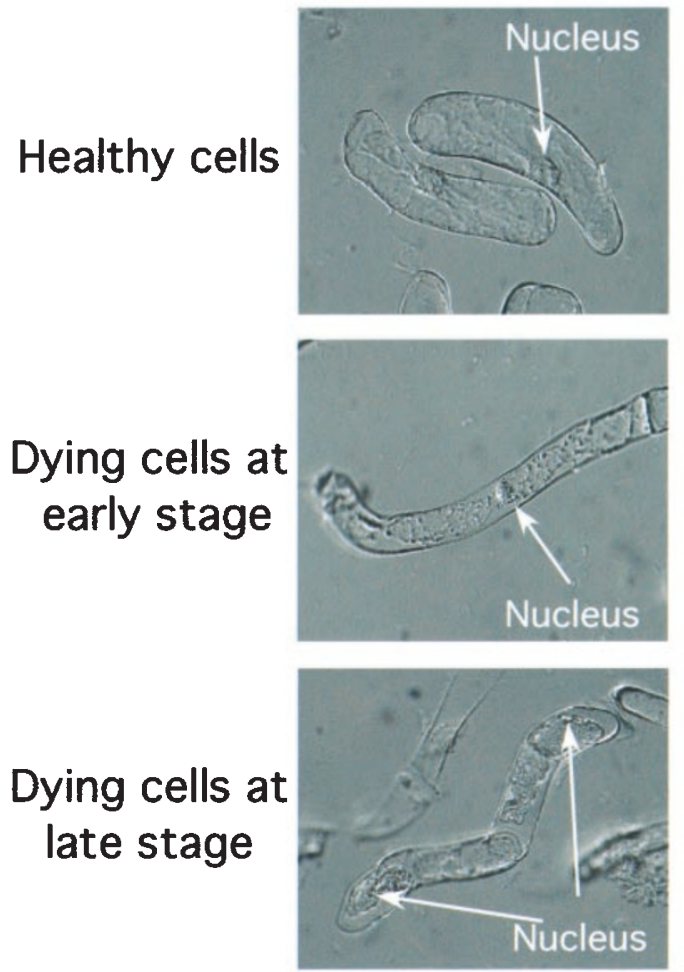

FDA
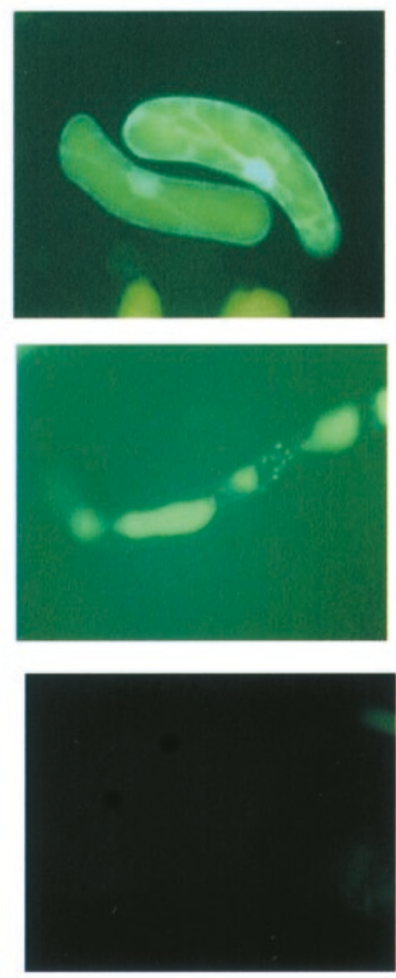

Bisbenzimide
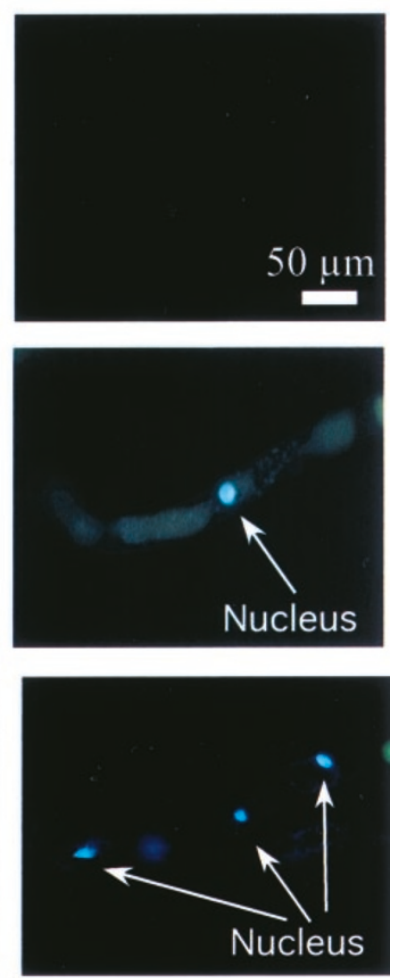

Figure 1 Morphological changes in dying tobacco cells. Cells were stained with FDA and bisbenzimide. Differential interference contrast (DIC) and fluorescent images were photographed. Bar represents $50 \mu \mathrm{m}$ 
above. The level of cell death was determined, and cytosolic protein extracts were subjected to immunoblot analysis with anti-PR1 basic antibodies (Figure 2C). The PR1-basic protein was detected at $6 \mathrm{~h}$ in response to EIX and STS treatment, but only in the absence of $\mathrm{CHX}$ (Figure 2C). The cells undergo PCD irrespectively of the presence or absence of $\mathrm{CHX}$ as mentioned above (Figure $2 \mathrm{C}$ ). These results show that PR-1 basic synthesis is induced by EIX, as shown previously, ${ }^{30,32}$ and by STS, as shown here. Moreover, tobacco cell suspensions were labeled with ${ }^{35} \mathrm{~S}$ Methionine in the presence or absence of $\mathrm{CHX}$. Labeled proteins were identified only in the absence of $\mathrm{CHX}$ (data not shown). It seems therefore that $\mathrm{CHX}$ can inhibit protein synthesis in the tobacco cell suspension, but does not inhibit the induction of PCD (Figure 2).

\section{Caspase inhibitors suppress EIX and STS induced PCD in tobacco cells}

To determine whether caspase-like proteases are part of the basic machinery of plant PCD, we applied to tobacco cell cultures the cell permeable irreversible peptide caspase inhibitors zVAD-fmk or BocD-fmk, ${ }^{33,34}$ in order to irreversibly block caspase-like protease activity. N. tabacum cv Xanthi cell cultures were treated with the caspase inhibitor ZVAD-fmk 20 min before the application of EIX-CHX (Figure 3A) or STS$\mathrm{CHX}$ (Figure $3 \mathrm{~B}$ ). As can be seen in Figure 3, the induction of PCD by EIX-CHX or STS-CHX can be dramatically inhibited in the presence of $100 \mu \mathrm{M}$ of the caspase inhibitor zVAD-fmk. Moreover, a different caspase inhibitor, BocD-fmk, inhibits the induction of PCD by STS-CHX as well (Figure 3B), reducing the level of cell death to that of untreated cells. Treatment of cells with an irrelevant caspase inhibitor, a cell permeable cathepsin B inhibitor zFA-fmk, followed by application of STS$\mathrm{CHX}$ did not block induction of PCD (Figure $3 \mathrm{~B}$ ). These results strongly suggest that the induction of cell death in tobacco cells by EIX-CHX and STS-CHX is mediated by caspase-like activity.

Cell permeable caspase inhibitors can reverse the induction of PCD and block the morphological changes that tobacco cells undergo under the influence of EIX-CHX or STS-CHX (data not shown). Cells treated for $6 \mathrm{~h}$ with
A

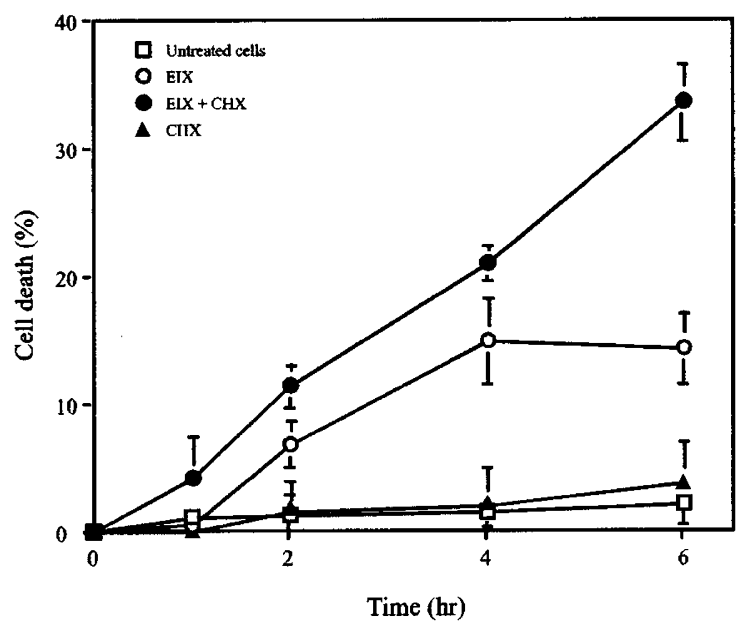

$\mathrm{C}$
B

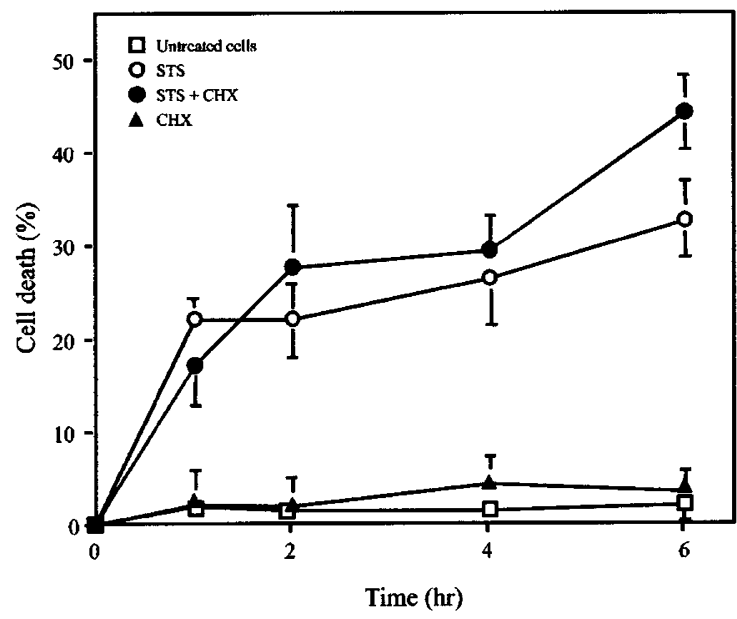

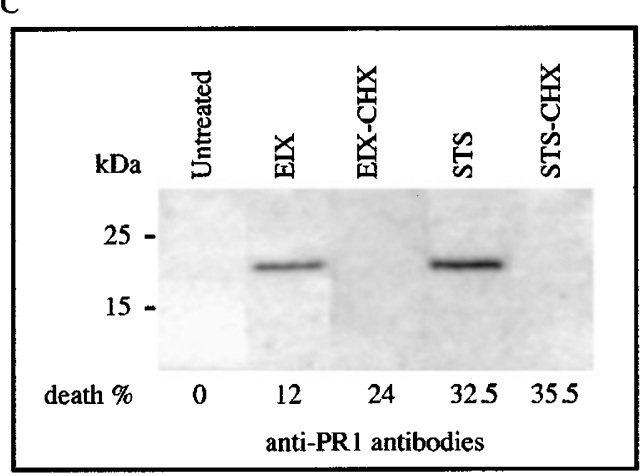

Figure 2 Induction of cell death by EIX and Staurosporine. (A) N. tabacum cv Xanthi cell culture was incubated for different times as indicated in $3 \mu \mathrm{g} / \mathrm{ml}$ EIX, $10 \mu \mathrm{g} / \mathrm{ml} \mathrm{CHX}$, or a combination of both, and untreated cells. (B) N. tabacum cv Xanthi cell culture was incubated for different times as indicated in $50 \mu \mathrm{M}$ STS, $10 \mu \mathrm{g} / \mathrm{ml} \mathrm{CHX}$, or both and untreated cells. Each data point represents the percentage of dead cells counted of a population of at least 200 cells, in three individual experiments. Cell death was assessed morphologically. (C) N. tabacum cv Xanthi cell culture was incubated as indicated for $6 \mathrm{~h}$ in EIX (3 $\mu \mathrm{g} / \mathrm{ml})$, STS (50 $\mu \mathrm{M})$ with or without CHX (10 $\mu \mathrm{g} / \mathrm{ml})$. Total cytosolic proteins $60(\mu \mathrm{g} / \mathrm{lane})$ were separated on a $12 \%$ SDS-polyacrylamide gel, transferred to a nitrocellulose filter, and probed with anti-PR1 basic antibodies 
A

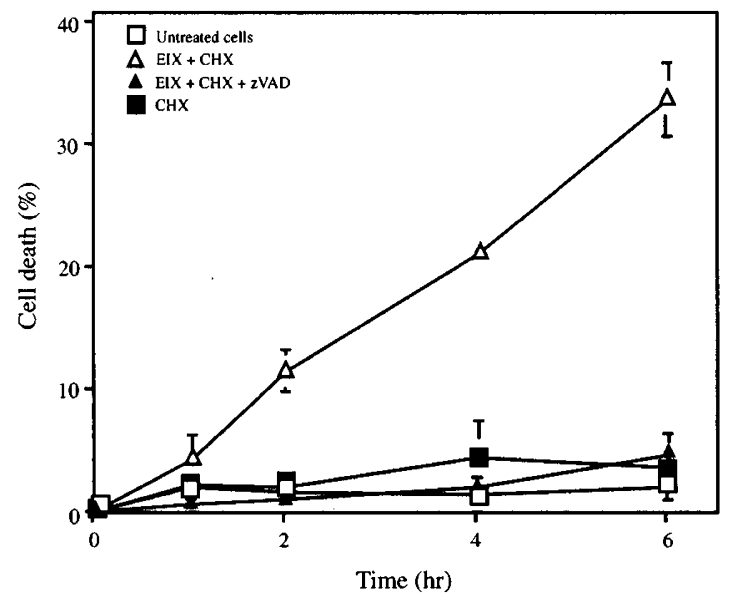

B

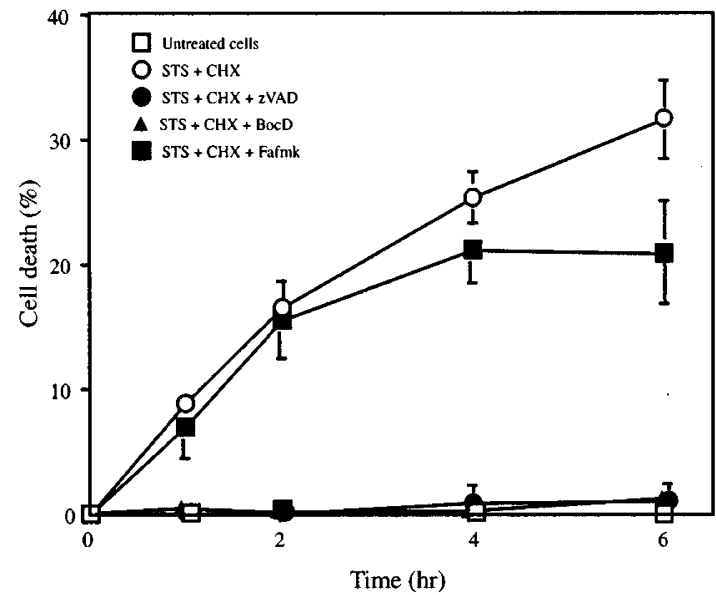

Figure 3 Inhibition of EIX and STS induced PCD by caspase inhibitors. (A) N. tabacum cv Xanthi cell culture was incubated for different times as indicated in $10 \mu \mathrm{g} / \mathrm{ml} \mathrm{CHX}, 3 \mu \mathrm{g} / \mathrm{ml}$ EIX and $10 \mu \mathrm{g} / \mathrm{ml} \mathrm{CHX}$, or with the addition of $100 \mu \mathrm{M}$ zVAD-fmk, as well as untreated cells. (B) $N$. tabacum cv Xanthi cell culture was incubated for different times as indicated in $50 \mu \mathrm{M} \mathrm{STS}$ and $10 \mu \mathrm{g} / \mathrm{ml} \mathrm{CHX}$, or with the addition of $100 \mu \mathrm{M}$ zVAD-fmk, $100 \mu \mathrm{M}$ BocD-fmk, $100 \mu \mathrm{M}$ zFA-fmk and untreated cells. Each data point represents the percentage of dead cells counted of a population of at least 200 cells, in three individual experiments

STS-CHX or EIX-CHX show advanced death morphology, while cells treated in the same way but in the presence of zVAD-fmk show normal cell morphology.

\section{Localization of caspase-like proteins in cells undergoing PCD}

Peptide caspase inhibitors were shown to bind specifically to activated caspase proteases. ${ }^{34-36}$ We showed that the caspase inhibitor zVAD-fmk inhibits the induction of PCD by the fungal elicitor EIX or the protein kinase inhibitor STS (Figure 3). We used a fluoroisothiocyanate (FITC) conjugate of the cell permeable caspase inhibitor VAD-fmk ${ }^{37}$ to localized caspase-like proteins during the induction of PCD (Figure 4). Tobacco cell culture was treated with STS $(50 \mu \mathrm{M})$ and $\mathrm{CHX}$ $(10 \mu \mathrm{g} / \mathrm{ml})$. Following STS-CHX treatment, FITC labeled VAD-fmk $(10 \mu \mathrm{M})$ was added and proteins labeled with FITC VAD-fmk were visualized (Figure 4). We found that treatment with $10 \mu \mathrm{M}$ FITC labeled VAD-fmk is below the biological threshold level in our experiments: PCD induction was not blocked. The labeled VAD-fmk inhibitor does not bind proteins in untreated, living cells, and hence, no FITC labeled VAD-fmk is visible (Figure $4 \mathrm{~K}$ ). The morphology of these cells, both in DIC imaging and with bisbenzimide staining (Figure 4A,F), corresponds with normal looking cells. To demonstrate that this observation is not due to reduced permeability of FITC labeled VAD-fmk, untreated cells were fixed with $4 \%$ paraformaldehyde and then stained with bisbenzimide or FITC labeled VAD-fmk. The DIC imaging of the fixed cells (Figure $4 \mathrm{~B}$ ) is similar to that of the unfixed cells (Figure 4A). Fixed cells are permeable, and thus-can be stained with bisbenzimide (Figure 4G). However, fixed cells do not stain with FITC labeled VAD-fmk (Figure 4), suggesting that the inability of FITC-VAD-fmk to stain proteins in untreated cells is not due to an inability of FITC-VAD-fmk to penetrate the cells. STS-CHX treated cells exhibiting early death stages (Figure $4 \mathrm{C}, \mathrm{H})$ are labeled by FITC-VAD-fmk in their cytoplasm only, and by bisbenzimide in their cell cytoplasm and nucleus (Figure 4H,M). STS-CHX treated cells undergoing a late stage of death show FITC-VAD-fmk labeled proteins primarily localized to the nucleus, intensive bisbenzimide staining in the nucleus and condensation of the cytoplasm (Figure 4D,I,N).

In order to demonstrate that FITC-VAD-fmk labels specific proteins in the tobacco cell culture, we performed a competitive binding experiment. Following pre-treatment with a 10-fold concentration of unlabeled zVAD-fmk $(100 \mu \mathrm{M})$ cells were treated with STS-CHX and FITCVAD-fmk $(10 \mu \mathrm{M})$. These cells show normal morphology, do not stain with FITC-VAD-fmk or bisbenzimide and their cytoplasm looks normal (Figure 4E,J,O). This experiment suggests that FITC labeled VAD-fmk binds specifically to plant proteins, which may be responsible for the morphological changes observed in the cells during STS-CHX induced PCD. Similar to mammalian cells, ${ }^{38}$ active plant caspase-like proteins can be found initially in the cytoplasm and at a later stage of the death program, in the nucleus.

\section{The caspase inhibitor zVAD-fmk binds specifically to proteins in a tobacco cytosolic extract}

We have shown here that ZVAD-fmk inhibits STS and EIX induced cell death in $N$. tabacum cv Xanthi cell culture (Figure 3 ) and binds cytosolic proteins in cells undergoing PCD (Figure 4). We proceeded to characterize the proteins that bind zVAD-fmk in plant cell extracts. $N$. tabacum cv Xanthi cell culture was incubated with $\operatorname{EIX~}(3 \mu \mathrm{g} / \mathrm{ml})$ and $\mathrm{CHX}(10 \mu \mathrm{g} / \mathrm{ml})$ or STS $(50 \mu \mathrm{M})$ and $\mathrm{CHX}(10 \mu \mathrm{g} / \mathrm{ml})$. Total cytosolic proteins were extracted, and a cell free binding assay was conducted utilizing biotinylated VAD-fmk. Following incubation with the biotinylated caspase inhibitor, the cell extracts were separated on a SDS-polyacrylamide gel, blotted onto a nitrocellulose filter, and bound with streptavidin-HRP (Figure 5). In culture competition assays were performed to demonstrate 
Untreated

DIC

\section{Bisbenzimide}
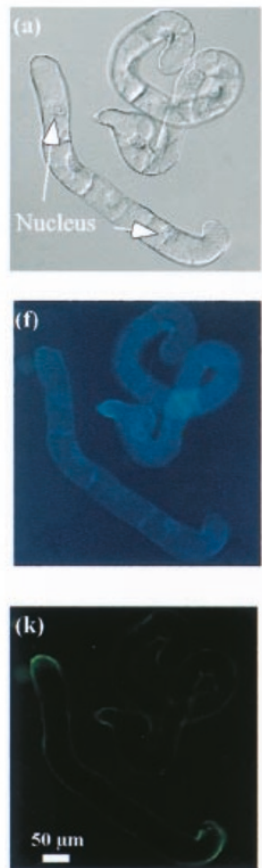

STS-CHX

Fixed cells
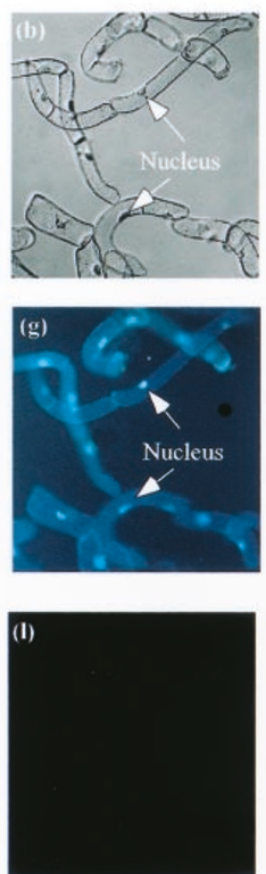

Late stage

Early stage
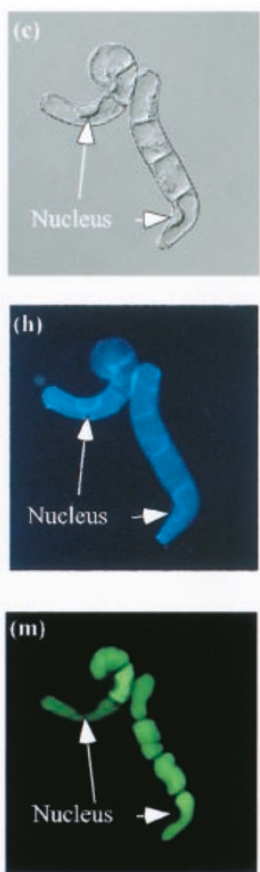

STS-CHX-zVAD
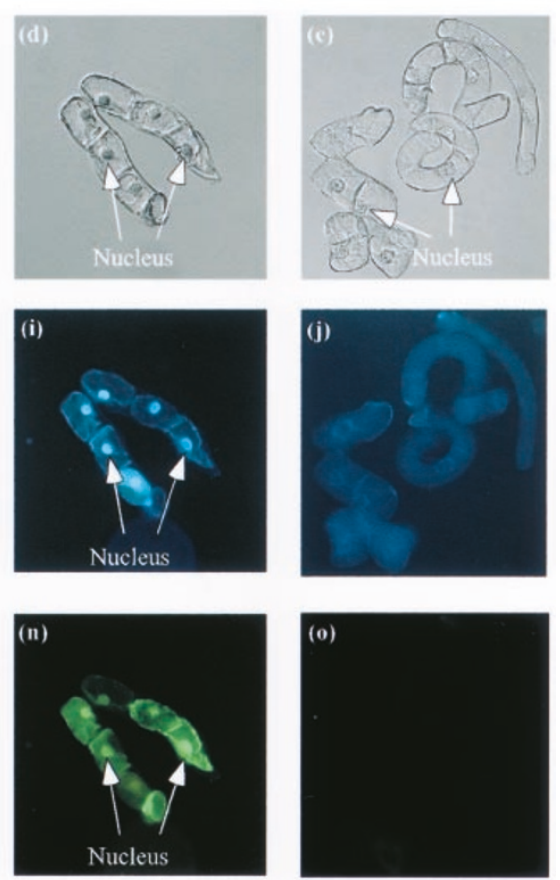

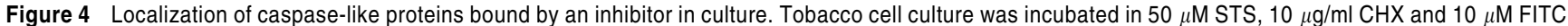
labeled VAD-fmk, with or without $100 \mu \mathrm{M}$ zVAD-fmk. (A-E) DIC imaging of untreated and treated cells. The above cells were photographed after bisbenzimide staining $(\mathbf{F}-\mathbf{J})$ or FITC-VAD-fmk labeling $(\mathbf{K}-\mathbf{0})$. Bar represents $50 \mu \mathrm{m}$
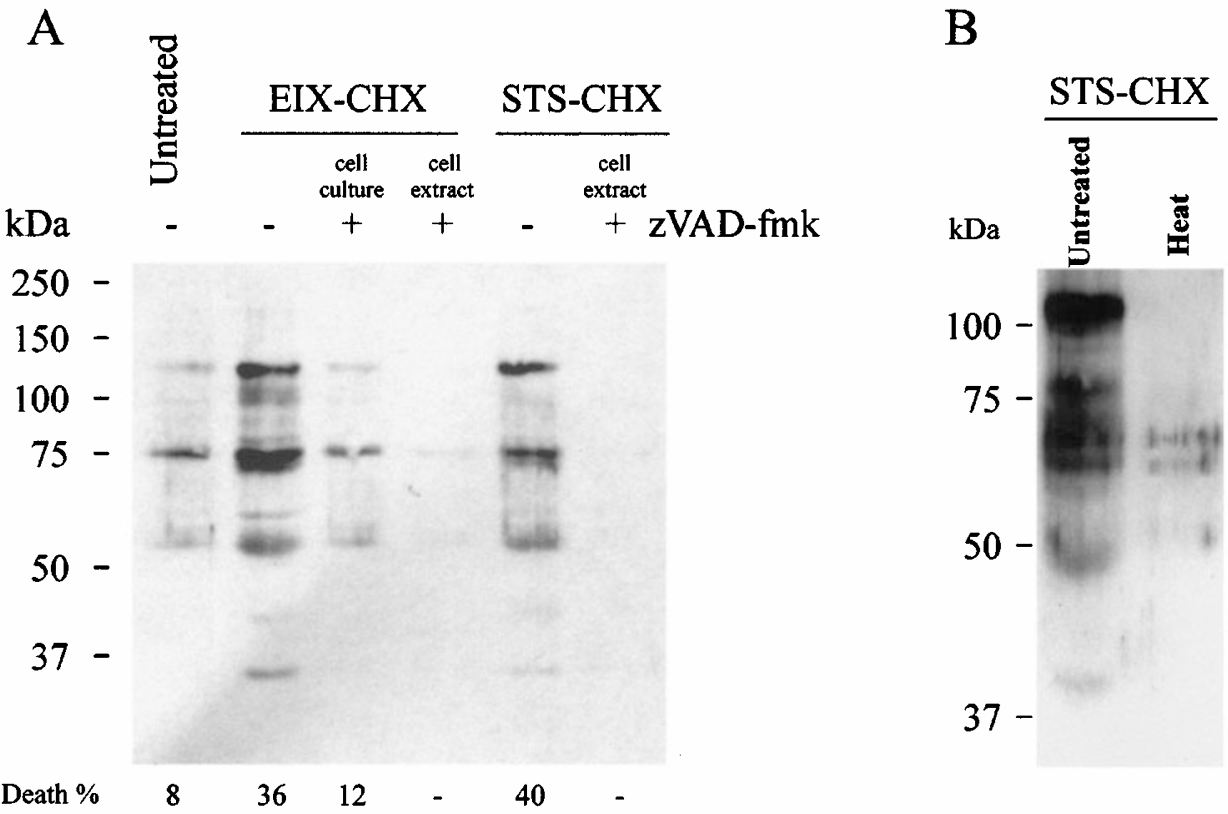

Figure 5 Binding of a caspase inhibitor to tobacco cytosolic proteins. (A) Tobacco cell culture was incubated for $6 \mathrm{~h}$ in $3 \mu \mathrm{g} / \mathrm{ml}$ EIX, with or without $100 \mu \mathrm{M}$ zVADfmk, or $50 \mu \mathrm{M}$ STS. Total cytosolic proteins were extracted and a binding assay with biotinylated-VAD-fmk $(250 \mu \mathrm{M})$ was conducted as described in Materials and Methods. Competitive binding assays were performed in culture with $100 \mu \mathrm{M}$ zVAD-fmk or in the cell free extract with $5 \mathrm{mM}$ zVAD-fmk. (B) Tobacco cell culture was incubated for $6 \mathrm{~h}$ in $50 \mu \mathrm{M} \mathrm{STS}$ and $10 \mu \mathrm{g} / \mathrm{ml} \mathrm{CHX}$. Total cytosolic proteins were heat treated at $65^{\circ} \mathrm{C}$ for 10 min prior to binding with biotinylated-VAD-fmk (250 $\left.\mu \mathrm{M}\right)$. Total cytosolic proteins $(60 \mu \mathrm{g} / \mathrm{lane}$ ) were separated on a 12\% SDS-polyacrylamide gel, transferred to a nitrocellulose filter, and probed with streptavidin-HRP 
that zVAD-fmk binds to specific proteins. $N$ tabacum $c$ Xanthi cell culture was treated with zVAD-fmk prior to treatment with EIX-CHX. Total cytosolic proteins were extracted, and a binding assay was conducted utilizing biotinylated VAD-fmk. Biotinylated proteins were detected as mentioned above (Figure 5a). In addition, in vivo competition assays were performed using the cell extracts by treatment of the above cytosolic proteins with excess zVAD-fmk prior to treatment with biotinylated VAD-fmk. As seen, upon the addition of zVAD-fmk in the cell culture, the banding pattern is similar to the banding pattern of the untreated sample (Figure $5 \mathrm{a}$ ). The amounts of VAD-fmk bound protein appear to be correlated to the percentage of cell death at the time the extracts were made. Cell extracts made from untreated tobacco cells in culture ( $8 \%$ death) showed much less bound material as compared to the lanes of EIX-CHX (36\% death) and STS$\mathrm{CHX}(40 \%$ death) treated cells. Non-biotinylated VAD-fmk competes successfully in the cell extract with the binding of the biotinylated compound, indicating the binding to be specific. This experiment shows that caspase-like proteins are found in tobacco cells extracts, and the amount of protein that binds the caspase inhibitor is correlated to the quantity of cell death.

Caspase inhibitors were shown to bind to a conformational site in mammalian caspases. ${ }^{34}$ In order to show that the inhibitor binds similarly to plant proteins, we conducted a heating experiment. Cytosolic extracts prepared from STS-CHX treated cells were heated at $65^{\circ} \mathrm{C}$ for $10 \mathrm{~min}$, prior to binding with biotinylated VAD-fmk. Biotinylated-VAD conjugated proteins were detected as mentioned above (Figure 5B). Heating the extracts prior to incubation with biotinylated VAD-fmk greatly diminishes binding, indicating that the binding is dependent on the conformation of the protein (Figure 5B). This indicates further similarity to mammalian systems. ${ }^{34,35}$

\section{Discussion}

The present study characterizes some of the basic features of PCD in plants. We have shown morphological and functional similarities between plant and animal PCD.

The sequence of cellular morphological changes in tobacco cells undergoing PCD that we describe here (Figure 1) resembles classical animal apoptosis. Nevertheless, we found that loss of plasma membrane integrity, judged by bisbenzimide nuclear staining (Figure 1), occurs relatively early in plant cells while in animal cells, this is one of the last events to occur in apoptosis. ${ }^{39}$

We find that plant cells of $N$. tabacum cv Xanthi are capable of undergoing PCD through constitutively expressed machinery, as shown in the experiments using STS or EIX to induce PCD with the addition of $\mathrm{CHX}$ (Figure 2). Moreover, $\mathrm{CHX}$ treatment seems to enhance the PCD induced by EIX (Figure 2). This suggests that protein synthesis may be required for controlling the level of cell death, but not its execution. Several lines of evidence suggest that plant programmed cell death results from activation of an intrinsic program. ${ }^{40,41}$ Similarly, we have found that the induction of PCD by the fungal elicitor EIX or by the protein kinase inhibitor STS does not require protein synthesis. Conceptually, this suggests that plant cells are capable of dying in response to external signals by activating an intrinsic suicide program that kills the cells when needed.

Our data suggests that plants, like mammalians, ${ }^{7}$ possess constitutively expressed PCD machinery, which resides in the cell cytoplasm (Figure 4), in an inactive state, waiting to receive activation signals and execute cell death if necessary.

We demonstrated that caspase-like activity in tobacco cells might be responsible for the execution of PCD when induced with STS-CHX or with EIX-CHX. This conclusion can be made on the basis of our observation that PCD is completely blocked in tobacco cells by the caspase inhibitors zVAD-fmk and BocD-fmk (Figure 3). Moreover, using FITC labeled VAD-fmk we were able to show that during activation of plant PCD, caspase-like proteins are activated initially in the cytoplasm, and later in the cell nucleus (Figure 4). These caspase-like proteins can be labeled with the caspase inhibitor only during the PCD process (Figure 4); FITC labeled VAD-fmk does not bind proteins in untreated healthy cells. Moreover, zVAD-bound proteins were detected in tobacco cytosols using biotinVAD-fmk (Figure 5), and the amount of protein available to bind $\mathrm{ZVAD}$ is correlated to the percentage of death in the cell culture.

Similar to the finding of dePozo and Lam, ${ }^{21}$ inhibition of PCD by the caspase inhibitor zVAD-fmk is a common characteristic between animal and plant PCD. Our data correlates with the findings of caspase 3-like activity in plant cells, ${ }^{25}$ but contradicts the results of Levine et al. and Suzuki et al., ${ }^{24,42}$ that caspase inhibitors do not inhibit plant cell death. This discrepancy may be due to the different systems used to measure cell death, different types of caspase-inhibitors used (some of which are not cell permeable) or differences in the inhibitor concentrations used. Since the plant cell wall may tend to adsorb a certain amount of the compounds added to the cell culture, a higher concentration than used in animals is necessary in order to observe a biological effect. Additionally, it is possible that the compounds used, which were originally designed for animal research, were not recognized as well in the plant cell; this would also indicate the necessity of higher concentrations.

Searching plant databases with mammalian caspase sequences revealed no homologous proteins or DNA sequences. Although caspase-like activity has been reported in several plant systems, ${ }^{20}$ no caspase-like proteins have been isolated from plants to date. It is our belief, considering the growing evidence of resemblance between plant and animal PCD systems in general, and the many recent reports of caspase-like activity in plants in particular, that caspase-like proteins most probably exist in plants. Recently, using the caspase-like domain of the Dictyostelium sequence as a query for a PSI-BLAST search, a distantly related family of caspase-like proteins was identified in the Arabidopsis genome. ${ }^{43}$ This gene family bears low resemblance to mammalian caspases. ${ }^{43}$ Moreover, its biological function has not yet been determined and, indeed, no proteins showing caspase 
activity have been isolated from plants to date. Since we were able to identify plant caspase-like proteins using a biotinylated caspase inhibitor, and to show that the binding of the caspase inhibitor to these proteins is correlated with the percentage of cell death and is specific (using competition assays and heat treatment experiments), it is our belief that although animal caspases and plant caspase-like proteins may share very little sequence similarity, they probably share similar biological activity.

In conclusion, our findings demonstrate that plant cells undergo PCD through constitutively expressed machinery. This machinery involves caspase-like proteins and can be activated by induction with EIX or STS.

\section{Materials and Methods}

\section{Cell culture growth and media}

N. tabacum cv Xanthi cell culture was grown in Murashige and Skoog (MS) media ${ }^{44}$ containing $0.1 \mu \mathrm{g} / \mathrm{l}$ 2-4-D (Sigma) and supplemented with $3 \%$ sucrose. Cells suspensions were maintained at $25^{\circ} \mathrm{C}$ and subcultured once a week.

\section{Cell culture assays}

N. tabacum cv Xanthi cell culture was incubated in 12-well tissue culture plates, $1 \mathrm{ml}$ culture per well, for up to $24 \mathrm{~h}$. At each time point, $100 \mu \mathrm{l}$ of the culture was removed, washed several times in culture media and mixed with $4 \mu \mathrm{g} / \mathrm{ml}$ bisbenzimide (Hoechst 33342, Sigma) or $10 \mu \mathrm{g} / \mathrm{ml}$ fluorescein-diacetate (FDA, Sigma). The cells were examined by light and fluorescent microscopy (Axioplan Microscope; Zeiss, Germany) using differential interference contrast imaging (DIC), $360 / 460 \mathrm{~nm}$ filter for bisbenzimide, and $485 / 520 \mathrm{~nm}$ filter for FDA and FITC. Cell death was assessed by both morphological and fluorescent staining criteria. Quantitative experiments were repeated three times and for each time point at least 200 cells were counted. The percentage of dead cells was calculated from the total of cells scored, after subtracting the basal amount of dead cells (which was assessed in the same manner prior to the beginning of each experiment). Only cell cultures with less than $10 \%$ initial death were chosen for our assays.

\section{Cell culture treatment}

N. tabacum cv Xanthi cell culture was incubated in MS media with the addition of the PCD inducers $3 \mu \mathrm{g} / \mathrm{ml}$ EIX or $50 \mu \mathrm{M}$ STS (Sigma) alone or together with $10 \mu \mathrm{g} / \mathrm{ml} \mathrm{CHX} \mathrm{(Sigma)} \mathrm{and} \mathrm{the} \mathrm{caspase} \mathrm{inhibitors}$ $10 \mu \mathrm{M}$ FITC-VAD-fmk (Promega), $100 \mu \mathrm{M}$ zVAD-fmk, $100 \mu \mathrm{M}$ BocDfmk, $100 \mu \mathrm{M}$ zFA-fmk (Enzyme system products) used alone or combined with the above mentioned inducers. The caspase inhibitors were added to the medium 20 min before the PCD inducers EIX or STS. Cells were incubated for various times and examined as mentioned above.

\section{Cytosolic protein extraction}

Total cytosolic proteins were extracted according to del Pozo and Lam (1998). Briefly, $10 \mathrm{ml}$ cells of a 4-5 day old cell culture were harvested. Cells were ground in liquid $\mathrm{N}_{2}$ to a fine powder with mortar and pestle and $1 \mathrm{ml}$ extraction buffer (50 mM HEPES, pH 7.5, 20\% glycerol, $1 \mathrm{mM}$ EDTA, $1 \mathrm{mM}$ DTT, 1\% BSA, $1 \mathrm{mM} \mathrm{PMSF)}$ was added.
Samples were centrifuged twice at $20000 \times g$ for $15 \mathrm{~min}$, to remove cell debris. Cytosolic extracts were stored at $-80^{\circ} \mathrm{C}$ until use.

\section{Binding of ZVAD to cytosolic proteins}

Biotin-VAD-fmk (250 $\mu \mathrm{M})$ was added to $150 \mu \mathrm{g}$ total cytosolic proteins, in a final volume of $150 \mu \mathrm{l}$, and the binding was conducted in room temperature for $2 \mathrm{~h}$ with gentle shaking ( 25 r.p.m.). The competitive binding assays were conducted by first adding $5 \mathrm{mM}$ of zVAD-fmk under the above binding conditions, and after $2 \mathrm{~h}$, adding $250 \mu \mathrm{M}$ Biotin-VAD-fmk for an additional $2 \mathrm{~h}$. (Incubation at room temperature for up to $10 \mathrm{~h}$ was found not to cause protein degradation, although the binding reaction reached a maximum after $\sim 2 \mathrm{~h}$ ).

\section{Protein analysis}

Biotin-VAD-fmk bound proteins $(50 \mu \mathrm{g})$ were analyzed by $12 \%$ polyacrylamide gel electrophoresis in the presence of SDS, ${ }^{45}$ transferred to a nitrocellulose filter and probed with streptavidin conjugated HRP (Jackson).

\section{Acknowledgements}

We are grateful to Drs. M Edelman, MC Raff and A Razin for helpful suggestions and discussions. This research was supported in part by the Israel Science Foundation administrated by the Israel Academy of Science and Humanities.

\section{References}

1. Gilchrist DG (1998) Programmed cell death in plant disease: The purpose and promise of cellular suicide. Annu. Rev. Phytopathol. 36: 393-414

2. Lam E, Pontier D and del Pozo O (1999) Die and let live - programmed cell death in plants. Curr. Opin. Plant Biol. 2: 502-507

3. Richberg MH, Aviv DH and Dangl JL (1998). Dead cells do tell tales. Curr. Opin. Plant Biol. 1: 480-485

4. Jacobson M, Weil M and Raff M (1997). Programmed cell death in animal development. Cell 88: 347-354

5. Raff M (1998) Cell suicide for beginners. Nature 396: 119-122

6. Vaux D, Korsmeyer S (1999) Cell death in development. Cell 96: 245-254

7. Weil M, Jacobson MD, Coles HS, Davies TJ, Gardner RL, Raff KD and Raff MC (1996) Constitutive expression of the machinery for programmed cell death. J. Cell Biol. 133: 1053-1059

8. TomeiL, Cope F(1991). Apoptosis: the molecularbasis of cell death. Cold Spring Harbor: Cold spring Harbor Lab. Press, 246

9. Wolf B and Green D (1999) Suicidal tendencies: apoptotic cell death by caspase family proteinases. J. Biol. Chem 274: 20049-20052

10. Greenberg JT (1996) Programmed cell death: a way of life for plants. Proc. Natl. Acad. Sci. USA 93: 12094-12097

11. Shirasu $K$ and Schulze-Lefert $P$ (2000) Regulators of cell death in disease resistance. Plant Molecular Biology 44: 371-385

12. Morel JB and Dangl JL (1997) The hypersensitive response and the induction of cell death in plants. Cell Death Differ. 4: 671-683

13. Heath MC (2000) Hypersensitive response-related death. Plant Mol. Biol. 44: $321-334$

14. Hammond-Kosack KE, Silverman P, Raskin I and Jones JDG (1996) Racespecific elicitors of Cladosporium fulvum induce changes in cell morphology and the synthesis of ethylene and salicylic acid in tomato plants carrying the corresponding Cf disease resistance gene. Plant Physiology 110: 1381-1394

15. Clough SJ, Fengler KA, Yu IC, Lippok B, Smith Jr. RK and Bent AF (2000) The Arabidopsis dnd1 'defense, no death' gene encodes a mutated cyclic nucleotidegated ion channel. Proc. Natl. Acad. Sci. USA 97: 9323-9328 
16. Bailey BA, Taylor R, Dean JFD and Anderson JD (1991) Ethylene biosynthesisinducing endoxylanase is translocated through the xylem of Nicotiana tabacum cv Xanthi plants. Plant Physiol. 97: 1181-1186

17. Ron M, Kantety R, Martin GB, Avidan N, Eshed Y, Zamir D and Avni A (2000) High-resolution linkage analysis and physical characterization of the EIX responding locus in tomato. Theor. Appl. Genet. 100: 184-189

18. Yano A, Suzuki K, Uchimiya H and Shinshi H (1998) Induction of hypersensitive cell death by fungal protein in cultures of tobacco cells. Mol. Plant-Microbe Interact. 11: 115-123

19. Lam E, Kato $N$ and Lawton $M$ (2001) Programmed cell death, mitochondria and the plant hypersensitive response. Nature 411: 848-853

20. Lam E and del Pozo O (2000) Caspase-like protease involvementin the control of plant cell death. Plant Mol. Biol. 44: 417-428

21. del Pozo O and Lam E (1998) Caspases and programmed cell death in the hypersensitive response of plants to pathogens. Curr. Biol. 8: 1129-1132

22. Mittler $R$ and Lam $E$ (1995) In-situ detection of $n D N A$ fragmentation during the differentiation of tracheary elements in higher-plants. Plant Physiol. 108: 489493

23. Wang H, Li J, Bostock RM and Gilchrist DG (1996) Apoptosis: A functional paradigm for programmed plant cell death induced by a host-selective phytotoxin and invoked during development. Plant Cell 8: 375-391

24. Levine A, Pennell RI, Alvarez ME, Palmer R and Lamb C (1996) Calciummediated apoptosis in a plant hypersensitive disease resistance response. Curr. Biol. 6: 427-437

25. Korthout H, Berecki G, Bruin W, van duijn B and Wang M (2000) The presence and subcellular localization of caspase 3 -like proteinases in plant cells. FEBS Lett. 475: 139-144

26. D'Silva I, Poirier GG and Heath MC (1998) Activation of cysteine proteases in cowpea plants during the hypersensitive response - a form of programmed cell death. Exp. Cell Res. 245: 389-399

27. Sun $Y$, Zhao Y, Hong X and Zhai Z (1999). Cytochrome c release and caspase activation during menadione-induced apoptosis in plants. FEBS Lett. 462: 317 321

28. Jacobson MD, Weil Mand Raff MC (1996). Role of Ced-3/ICE-family proteases in staurosporine-induced programmed cell death. J. Cell Biol. 133: 1041-1051

29. Avni A, Bailey BA, Mattoo AK and Anderson JD (1994) Induction of ethylene biosynthesis in Nicotiana tabacum by a Trichoderma viride Xylanase is correlated to the accumulation of ACC synthase and ACC oxidase. Plant Physiol. 106: $1049-1055$

30. Lotan T and Fluhr R (1990) Xyalanase, a novel elicitor of pathogenesis-related proteins in tobacco, use a non-ethylene pathway for induction. Plant Physiol. 93 : $811-817$
31. Eyal Y, Meller Y, Lev-Yadun S and Fluhr R (1993) A basic-type PR-1 promotor directs ethylene responsiveness, vascular and abscission zone-specific expression. Plant J. 4: 225-234

32. Bailey BA, Avni A and Anderson JD (1995) The influence of ethylene and tissue age on the sensitivity of Xanthi tobacco leaves to Trichoderma viride xylanase. Plant Cell Physiol. 36: 1669-1676

33. Thornberry NA, Rano TA, Peterson EP, Rasper DM, Timkey T, Garcia-Calvo M, Houtzager VM, Nordstrom PA, Roy S, Vaillancourt JP, Chapman KT and Nicholson DW (1997) A combinatorial approach defines specificities of members of the caspase family and granzyme B. Functional relationships established for key mediators of apoptosis. J. Biol. Chem. 272: 17907-17911

34. Ekert PG, Silke J and Vaux DL (1999) Caspase inhibitors. Cell Death Differ. 6: $1081-1086$

35. Earnshaw WC, Martins LM and Kaufmann SH (1999) Mammalian caspases: Structure, activation, substrates, and functions during apoptosis. Annu. Rev. Biochem. 68: 383-424

36. Nicholson DW and Thornberry NA (1997) Caspases: killer proteases. Trends Biochem. Sci. 22: 299-306

37. O'Brien MA and Haak-Frendscho M (1999) In situ marker for caspase activity. Mol. Biol. Cell 10 Suppl.: 1106

38. Zhivotovsky B, Samali A, Gahm A and Orrenius S (1999) Caspases: their intracellular localization and translocation during apoptosis. Cell Death Differ. 6 : $644-651$

39. Jacobson MD, Burne JF and Raff MC (1994) Programmed cell death and Bcl-2 protection in the absence of a nucleus. EMBO J. 13: 1899-1910

40. Dangl JL, Dietrich RA and Richberg MH (1996) Death don't have no mercy: Cell death programs in plant-microbe interactions. Plant Cell 8: 1793-1807

41. McCabe PF and Leaver CJ (2000) Programmed cell death in cell cultures. Plant Mol. Biol. 44: 359-368

42. Suzuki K, Yano A and Shinshi H (1999) Slow and prolonged activation of the p47 protein kinase during hypersensitive cell death in a culture of tobacco cells. Plant Physiol. 119: 1465-1472

43. Uren GA, O'Rourke K, Aravind L, Pisabarro TM, Seshagiri S, Koonin VE and Dixit MV (2000) Identification of paracaspases and metacaspases: two ancient families of caspase-like proteins, one of which plays a key role in MALT lymphoma. Mol. Cell 6: 961-967

44. Murashige $T$ and Skoog $F$ (1962) A revised medium for rapid growth and bioassays with tobacco tissue cultures. Physiol. Planta. 15: 473-497

45. Laemmeli UK (1970) Cleavage of structural proteins during the assembly of the head of a bacteriophage T4. Nature 227: 680-685 